\title{
PRELIMINARY INVESTIGATION ON THE USE OF MORINGA OLEIFERA FOR THE PURIFICATION OF LEAD POLLUTED WASTEWATER
}

\author{
N. M. Ogarekpe ${ }^{1, *}$, I. T. Tenebe ${ }^{2}$, P. C. Emenike ${ }^{3}$, R. E. Antigha ${ }^{4}$, I. E. Bassey ${ }^{5}$, I. C. Attah ${ }^{6}$ \\ and E. E. Ekeng ${ }^{7}$ \\ 1, 4, 5, 7, Dept. of Civil Engineering, Cross River University of TeChnology, Calabar, Cross River State, Nigeria \\ 2, 3, DEPARTMENT OF CIVIL ENGINEERING, COVENANT UNIVERSITY, OTA, OGUN STATE, NIGERIA \\ 6, Department of Civil Engineering, AKWa Ibom State University, MkPAT-Enin, AKWa Ibom State. NIGERIA \\ E-mail addresses: ${ }^{1}$ nkpaogarekpe@yahoo.com, ${ }^{2}$ imokhai.tenebe@convenantuniversity.edu.ng, \\ 3 praisegod.emenike@convenantuniversity.edu.ng, ${ }^{4}$ revantiga@gmail.com, ${ }^{5}$ index_2k6@yahoo.com, \\ 6attahimoh@gmail.com, 7 ekengemmanuel@yahoo.com
}

\begin{abstract}
The need for low-cost wastewater treatment alternatives especially in poor hinterlands, where synthetic coagulants or activated carbon may not be cheaply and readily available, necessitated this study. Moringa Oleifera (MO) kernel was investigated as coagulant in the purification of wastewater polluted with lead. The adsorption potential of MO was also investigated. MO with effective size of $0.14 \mathrm{~mm}$ was used in the preparation of stock solutions with dosages of $500 \mathrm{mg} / \mathrm{I}$ and $1000 \mathrm{mg} / \mathrm{l}$. Synthetic wastewater polluted with lead monoxide was prepared. The wastewater had an initial concentration of $0.216 \mathrm{mg} / \mathrm{l}$ of lead. $2 \%, 4 \%, 6 \%, 8 \%$ and $10 \%$ of the stock solutions were added to the wastewater samples. The samples were subjected to jar test experiments. The research revealed that efficiency of lead removal increases with increase in the concentration of the MO coagulant. For one hour contact time, a maximum efficiency of $35.2 \%$ of lead removal was achieved when $10 \%$ of the stock solution $(1000 \mathrm{mg} / \mathrm{l}$ solution) was added. The fitting of the experimental data with the Langmuir and Freundlich adsorption isotherm models yielded $R^{2}$ values of 0.784 and 0.906 , respectively for the $1000 \mathrm{mg} / \mathrm{l}$ dosage stock solution. Freundlich model described the lead (Pb) adsorption better than the Langmuir model. Chemisorption was suggested to be involved in lead (Pb) adsorption (adsorption intensity $n<1$ ). The utilization of the extraction method presented in this research proposes the combination of the MO coagulants with the inorganic coagulants.
\end{abstract}

Key words: Investigation; Moringa Olifera; lead; purification; wastewater

\section{INTRODUCTION}

Water is a critical life sustenance resource. However, man's varied activities have continually resulted in the pollution of water. The presence of undesirable substances in water renders it unsafe for consumption. The susceptibility of lead ingestion cannot be ruled out in climes where solid waste management is poor. Some of the sources of lead include lead-acid battery, solder and alloys [1]. Also, water can be polluted with lead from water pipes and joints [2].
In the past, several treatment techniques have been utilized in the removal of lead in water. These include the use of catonic resin purolite [3]; adsorption using high alumina content bauxite [4]; Alkali Ash Material Permeable Reactive Barrier [5]; the use of specific lactic acid bacteria [6]; electrocoagulation process [7]; adsorption using natural American bentonite and activated carbon [8]; using Synthesized Iron Nanoparticles [9]; using okra [10]; the use of rice hush, maize and saw dust [11].

The use of adsorption techniques in the treatment of heavy metal wastewater has gained a lot of

\footnotetext{
* Corresponding author, tel: +234-803-265- 1621
} 
popularity [12]. Adsorption is the prevention of the movement of adsorbates on the adsorbent [13]. Isotherm adsorption models have been used in wastewater treatment to predict the ability of certain adsorbents to remove pollutants $[8,11,14]$. Among many, the Langmuir and Freundlich adsorption isotherm models, have been used by various researchers. The amount of lead adsorbed on the MO after one hour contact time was calculated using the Equation (1) [15]

$$
q_{e}=\frac{V}{m}\left(C_{o}-C_{e}\right)
$$

where $C_{0}$ and $C_{e}(\mathrm{mg} / \mathrm{l})$ are the initial and the final concentrations of adsorbates, respectively, $\mathrm{V}$ is the volume of the solution (in litres) and $\mathrm{m}$ is the mass of dry adsorbent used (in grammes), $q_{e}$ is the units of mass adsorbate/mass adsorbent, or mole adsorbate/mass adsorbent.

The Langmuir isotherm model is given as shown in Equation (2) [16]

$$
q_{e=} \frac{q_{m} b C_{e}}{\left(1+b C_{e}\right)}
$$

Where $C_{e}$ is the equilibrium concentration of solute in the bulk solution, $\mathrm{q}_{\mathrm{e}}$ is the amount of solute adsorbed per unit weight of adsorbent at equilibrium $(\mathrm{mg} / \mathrm{g})$, $\mathrm{q}_{\mathrm{m}}$ is maximum adsorption capacity $(\mathrm{mg} / \mathrm{g}), \mathrm{b}$ is Langmuir constant $\left(\mathrm{L} \mathrm{mg}^{-1}\right)$

The above Langmuir equation in its linearized form is given as shown in Equation (3).

$$
\frac{C_{e}}{q_{e}}=\frac{1}{b q_{m}}+\frac{C_{e}}{q_{m}}
$$

The Freundlich adsorption isotherm model is given as shown in Equation (4) [17]

$$
q_{e}=k_{f} C_{e} \frac{1}{n}
$$

Where $k_{f}$ is the Freundlich adsorption capacity ( $\mathrm{mg}^{1-}$ $\left.{ }^{(1 / n)} \mathrm{L}^{1 / n} \mathrm{~g}^{-1}\right), \mathrm{n}$ is dimensionless constant that represent the adsorption intensity. It is generally stated that values of $n$ in the range $2-10,1-2$ and $<1$ indicate, respectively, good, moderate and poor adsorption characteristics [4].

Equation (4) can also be expressed in the linearized logarithmic form as follows:

$$
\log q_{e}=\log k_{f}+\frac{1}{n} \log C_{e}
$$

There are many methods in which colloids can be destabilized in wastewater; one of which is the use of inorganic salts as coagulants. It is reported in Mesdaghinia et al. [18] that the use of ferric chloride and alum as coagulants results in the deterioration of the water quality due to the residual metals left as a result of under or over-dosing. Inferring from the finding of Mesdaghinia et al. [18], the use of ferric chloride and alum as coagulants may lead to the problems of sludge management and hence increasing the cost of treatment.

The need for alternatives to the use of inorganic salts gave birth to researches on the use of low cost and readily available materials. Pollard et al. [19] reviewed low-cost alternatives to activated carbon for waste and wastewater treatment is reviewed. Ali et al. [20] reported high efficiencies of turbidity removal with low dosages of Moringa Oleifera coagulants as compared with aluminum sulphate. Aho and Lagasi [21] applied MO as coagulant in place of Aluminium Sulphate (Alum) used in conventional treatment plants. Ghebremichael [22] stated that MO coagulant protein possessed coagulation and sludge conditioning properties as alum. Schwarz [23] stated that Moringa Oleifera seed kernels contain significant quantities of a series of low molecular-weight watersoluble proteins. Schwarz further stated that, in solution, the positively charged MO neutralizes the negatively charged particulates that make raw waters turbid.

The lack of modern wastewater treatment technologies coupled with the unavailability of skilled personnel, results in water contamination and perhaps, avoidable loss of lives especially in the hinterlands, consequent upon the unavailability of potable water. The need for low-cost wastewater treatment alternatives especially in poor hinterlands, where synthetic coagulants or activated carbon may not be cheaply available, necessitated this study.

\section{Materials and Methods \\ 2.1 Area of Study}

The study was carried out in Calabar, Nigeria. The analysis of the samples was carried out at Cross River State Water Board Limited laboratory. The lead monoxide, Moringa Oleifera pods was purchased from outlets and available sources in Calabar.

\subsection{Materials}

Dry Moringa Oleifera seeds were used for this study. The seeds were unshelled by hand and the kernels were properly washed with distilled water to remove any adhering dirt. The washed kernels were oven dried at $40^{\circ} \mathrm{C}$ for $24 \mathrm{hrs}$. The MO kernels were pulverized using mortar and pestle and the oil was extracted by soxhlet extraction using hexane as the extracting solvent. The extracted solids obtained was dried at room temperature in open air for one hour. 


\subsection{Material Classification}

The gradation of the dried extracted MO solids was determined by sieve analysis in accordance with the specifications in BS410 [24]. The dried MO extract was weighed $(50 \mathrm{~g})$ before being poured into the assembled sieve. The sample was placed on a shaker for 10 minutes. The stacks were removed from the shaker and the weight of each sieve with its retained sample were recorded. Percentages retained and cumulative percentages passing were calculated. Therefore, the effective size of the MO used for this study was determined as $0.14 \mathrm{~mm}$.

\subsection{Bioactive Constituent Removal}

The bioactive constituents were removed with zinc chloride solution. $100 \mathrm{~g}$ of an anhydrous Zinc Chloride was dissolved in $400 \mathrm{~mL}$ of distilled water. After which $50 \mathrm{~g}$ of the dried MO extract was added to the solution. The mixture was poured into an auto clave machine and heated for 30minutes. At the expiration of the heating period, it was allowed to cool. The supernatant liquid was discarded leaving the MO residue stock. The MO residue stock obtained was dried in an oven at a temperature of $40^{\circ} \mathrm{C}$ for 20 hours. The dried MO cake residue was subsequently utilized for the study.

\subsection{Description of Experimental Set-up}

The dried MO cake residue was used in the preparation of two sets of solutions with dosages of $500 \mathrm{mg} / \mathrm{l}$ and $1000 \mathrm{mg} / \mathrm{l}$. Consequently, $2 \%, 4 \%, 6 \%$, $8 \%$ and $10 \%$ (corresponding to $20 \mathrm{mg} / \mathrm{g}, 40 \mathrm{mg} / \mathrm{g}$, $60 \mathrm{mg} / \mathrm{g}, 80 \mathrm{mg} / \mathrm{g}$ and $100 \mathrm{mg} / \mathrm{g}$ of the MO cake residue) of each of the aforementioned concentrations were prepared. Also, synthetic wastewater polluted with lead monoxide, was prepared. Care was taken to ensure that an initial concentration of $0.216 \mathrm{mg} / \mathrm{l}$ of lead was achieved in the synthetic wastewater. The wastewater samples were put in fifteen $100 \mathrm{ml}$ beakers. $2 \%, 4 \%, 6 \%, 8 \%$ and $10 \%$ of the stock solutions from the two sets of aforementioned MO dosages were added to the wastewater samples. The measurement of the $\mathrm{pH}$ values of the samples was carried out using a $\mathrm{pH}$ meter ( $\mathrm{HACH}$ senION ${ }^{\mathrm{TM}}+\mathrm{pH} 31$ model). In order to enhance thorough mixing, the samples were rapidly stirred at 300 r.p.m. for 5 minutes and thereafter stirred at 30r.p.m for 7 minutes. The samples obtained were subjected to jar test experiments. The water samples were left for 1 hour under quiescent conditions to enhance undisturbed settling of the solids. Clear water sample obtained through the process of decantation was stored for further analysis. All the analyses were carried out using appropriate water testing meters and in accordance with the standard methods [25].

The concentrations of lead in the clear water samples were determined with the aid of a UV-Visible spectrophotometer (DR 5000 model). The efficiency of lead removal was computed using Equation (6).

$$
\text { Efficiency }=\frac{\left(C_{o}-C_{e}\right)}{C_{o}} \times 100
$$

\section{RESULTS AND DISCUSSION}

\subsection{Efficiency of Lead $(\mathrm{Pb})$ Removal}

The results revealed that the addition of $2 \%, 4 \%$, $6 \%, 8 \%$ and $10 \%$ of the stock solutions from $500 \mathrm{mg} / \mathrm{l} \mathrm{MO}$ dosage yielded efficiencies of removal of the lead pollutant ranging from $2.3-23.0 \%$, respectively, when subjected to one hour contact time. The minimum and maximum efficiencies of lead removal corresponded to the addition of dosages of $10 \mathrm{mg} / \mathrm{l}$ and $50 \mathrm{mg} / \mathrm{l}$ of the coagulant. Implying that the coagulant resulted in the destabilization of the pb ions. Similarly, the addition of $2 \%, 4 \%, 6 \%, 8 \%$ and $10 \%$ of the stock solutions from $1000 \mathrm{mg} / \mathrm{l} \mathrm{MO}$ dosage yielded efficiencies of removal of the lead pollutant ranging from $7.4-35.2 \%$, respectively, when subjected to one hour contact time. The minimum and maximum efficiencies of lead removal corresponded to the addition of dosages of $20 \mathrm{mg} / \mathrm{l}$ and $100 \mathrm{mg} / \mathrm{l}$ of the coagulant. Therefore, it can be inferred that for the concentrations of coagulant under review, the destabilization of the $\mathrm{Pb}$ ions was achieved within the limits herewith presented. A comparison of the results obtained for stock solutions with dosages of $500 \mathrm{mg} / \mathrm{l}$ and $1000 \mathrm{mg} / \mathrm{l}$ vis-à-vis their performance in the removal of lead reveals that the efficiency of lead removal increases with increase in the concentration of the MO coagulant (Figure 1).

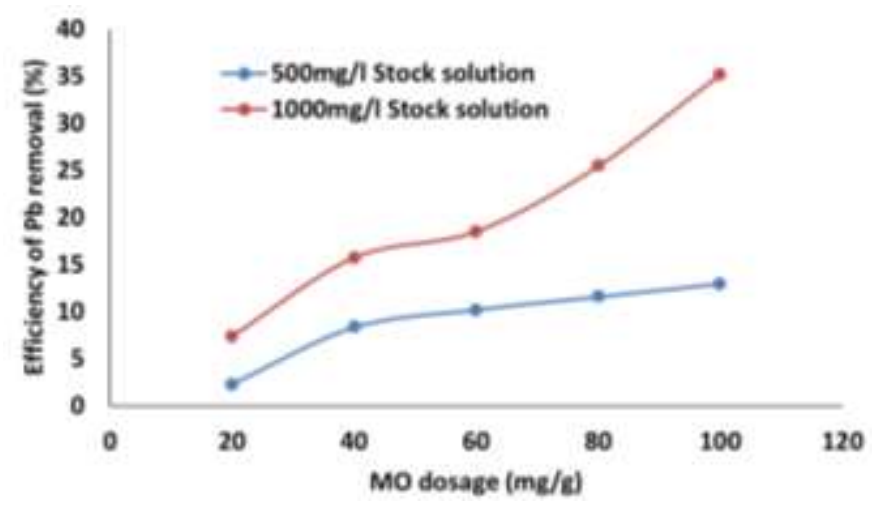

Figure 1: Effect of variable MO coagulant dosage on the efficiency of lead removal

Vol. 38, No.1, January, 2019 
The maximum efficiency of $35.2 \%$ of lead removal achieved when $10 \%$ of the stock solution $(1000 \mathrm{mg} / \mathrm{l}$ solution) was added corresponded to $0.14 \mathrm{mg} / \mathrm{l}$ of final concentrations of adsorbates. The final concentration of adsorbates of $0.14 \mathrm{mg} / \mathrm{l}$ was comparatively high considering the concentration of $0.01 \mathrm{mg} / \mathrm{l}$ stipulated in the guidelines for drinkingwater quality [1]. The low efficiencies of lead removal may be consequent upon the method of extraction of the MO. Therefore, in order to achieve high efficiencies of lead removal, the utilization of the extraction method presented in this research proposes the combination of the MO coagulants with the inorganic coagulants. However, higher efficiencies may perhaps be achieved if the contact time is increased beyond the one hour utilized in this study.

\subsection{Effect of MO Coagulant on pH}

An average $\mathrm{pH}$ of 7.24 and 7.75 were obtained before and after treatment. The slight change in $\mathrm{pH}$ presents an advantage over the use of inorganic salts for which significant modification in $\mathrm{pH}$ occurs. This would result in cost savings associated with either the reduction or increase of alkalinity of the treated wastewater as the case may be.

\subsection{Adsorption potentials of Moringa Oleifera}

The experimental data of the lead $(\mathrm{pb})$ adsorption to MO have been analyzed using the Langmuir and Freundlich isotherm models. The fitting of the experimental data with the Langmuir and Freundlich adsorption isotherm models yielded $\mathrm{R}^{2}$ values of 0.784 and 0.906 , respectively, as shown in Figures 2 and 3. This implied that for the range of concentrations $(20-100 \mathrm{mg} / \mathrm{l})$ of the MO studied, the Freundlich model described the lead $(\mathrm{Pb})$ adsorption better than the Langmuir model.

Chemisorption was suggested to be involved in lead (pb) adsorption (adsorption intensity $\mathrm{n}<1$ ) [26] as shown in Table 1. The study demonstrates that MO seed has the potential to be used as an adsorbent for the removal lead $(\mathrm{pb})$ from water.

\section{CONCLUSION}

Moringa Oleifera (MO) kernel was utilized as coagulant in the purification of wastewater polluted with lead. In addition, the adsorption potential of MO was also investigated. The study revealed that the efficiency of lead removal increases with increase in the concentration of the MO coagulant. However, the efficiencies of removal were low when subjected to one hour contact time. Therefore, the utilization of the extraction method presented in this research proposes the combination of the MO coagulants with the inorganic coagulants. The average $\mathrm{pH}$ of 7.24 and 7.75 were obtained before and after treatment. The slight change in $\mathrm{pH}$ presented cost savings opportunities as they might be little or no need for $\mathrm{pH}$ adjustment after treatment. Also, the research revealed that MO seed has the potential to be used as an adsorbent for the removal lead (pb) from water.

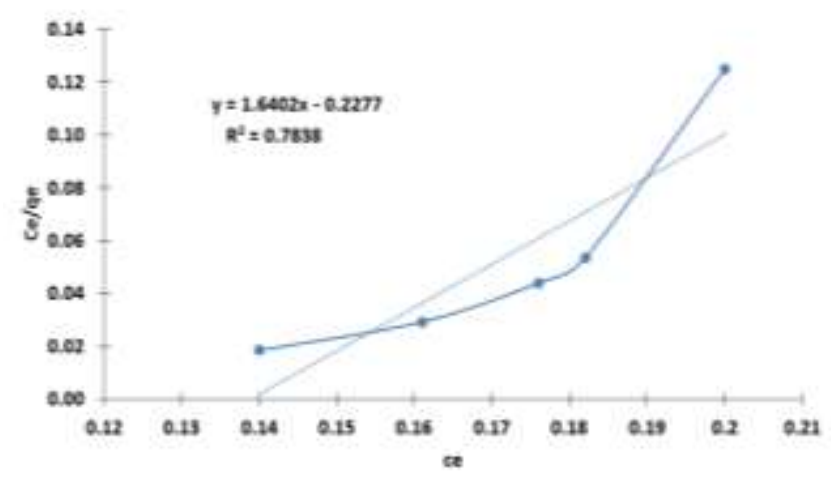

Figure 2: Langmuir adsorption isotherm plot for MO with concentrations ranging from $20-100 \mathrm{mg} / \mathrm{l}$

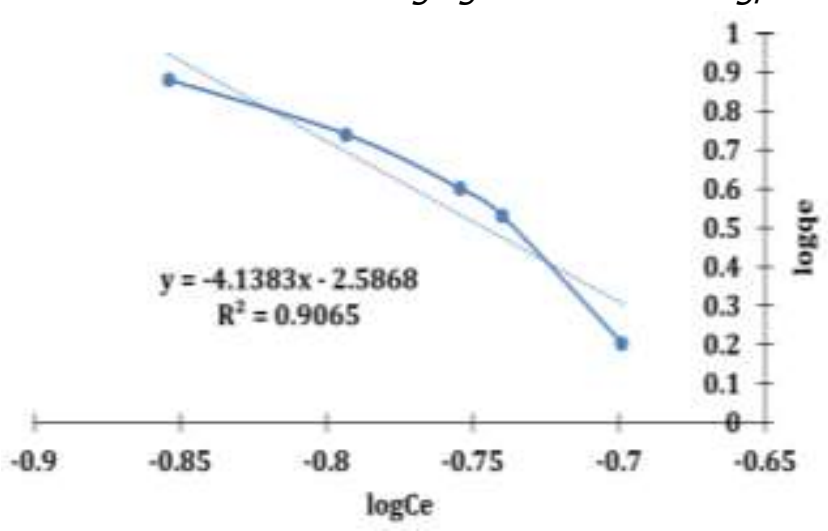

Figure 3: Freundlich adsorption isotherm plot for $M O$ with concentrations ranging from $20-100 \mathrm{mg} / \mathrm{I}$

Table 1: Kinetic models and their constants for adsorption of Pb to MO biomass for 1hour contact time

\begin{tabular}{lllllll}
\hline Biomass concentration & \multicolumn{5}{l}{ Langmuir Isotherm } & \multicolumn{4}{l}{ Freundlich Isotherm } \\
\hline & $\mathrm{q}_{\mathrm{m}}$ & $\mathrm{b}$ & $\mathrm{R}^{2}$ & $\mathrm{~K}_{\mathrm{f}}$ & $\mathrm{n}$ & $\mathrm{R}^{2}$ \\
\hline $\mathrm{MO}(20-100 \mathrm{mg} / \mathrm{l})$ & 0.61 & -7.2 & 0.784 & 0.0026 & -0.242 & 0.907 \\
\hline
\end{tabular}

All the units are as earlier defined 


\section{REFERENCES}

[1] World Health Organization. Guidelines for drinking water quality ( $4^{\text {th }}$ ed.). Geneva, Switzerland: Author, 2011.

[2] Lamley, A., Wagenet, L. and Kneen, B. Activated carbon treatment of drinking water. Fact Sheet 3, December, 1995.

[3] Merganpour, A. M., Nekuonam, G., Tomaj, O. A., Kor, Y., Safari, H., Karimi, K. and Kheirabadi, V. "Efficiency of lead removal from drinking water using cationic resin purolite". Environmental Health Engineering and Management Journal, 2 (1), pp. 4145, 2015.

[4] Lavecchia R., Medici F., Piga L., Rinaldi G. and Zuorro A. "Fluoride removal from water by adsoprtion on a high alumina content bauxite". Chemical Engineering Transactions, 26, pp. 225-230, 2012. DOI:10.3303/CET1226038.

[5] Brooks, R. M., Bahadory, M., Tovia, F. and Rostami, $\mathrm{H}$. "Removal of Lead from Contaminated Water". International Journal of Soil, Sediment and Water, 3(2) Article 14, 2010. Retrieved from http://scholarworks.umass.edu/intljssw/vol3/iss2/14.

[6] Halttunen, T., Salminen, S. and Tahvonen, R. "Rapid removal of lead and cadmium from water by specific lactic acid bacteria". International Journal of Food Microbiology, 114, pp. 30-35, 2007.

[7] Shakir, I.K. and Husein, B.I. "Lead removal from industrial wastewater by electrocoagulation process". Iraqi Journal of Chemical and Petroleum Engineering, 10(2), pp. 35 - 42, 2009.

[8] Yarkandi, N. H. "Removal of lead (II) from waste water by adsorption". Int. J. Curr. Microbiol. App. Sci., 3(4), pp. 207-228, 2014.

[9] Moezzi, A., Soltanali, S., Torabian, A. and Hasani, A. "Removal of lead from aquatic solution using synthesized iron nanoparticles". Int. J. Nanosci. Nanotechnol., 13(1), pp. 83 - 90, 2017.

[10] Hashem, M. A. "Adsorption of lead ions from aqueous solution by okra wastes". International Journal of Physical Sciences, 2(7), pp. 178 - 184, 2007.

[11] Abdel-Ghani, N. T., Hefny, M. and El-Chaghaby, G. A. F. "Removal of lead from aqueous solution using low cost abundantly available adsorbents". Int. J. Environ. Sci. Tech., 4 (1), pp. 67-73, 2007.

[12] Fu, F. and Wang, Q. "Removal of heavy metal ions from wastewaters: A review". Journal of Environmental Management, 92(3), pp. 407-418, 2011.

[13] Qasim, S. R., Motley, E. M. and Zhu, G. Water works engineering: Planning, design \& operation. New
Delhi: Asoke K. Ghosh, PHI Learning private limited, 2008.

[14] Emenike, P.C., Omole, D. O., Ngene, B.U. and Tenebe, I. T. "Assessment of $\mathrm{KOH}$-activated unripe Musa paradisiaca peel for adsorption of copper from aqueous solution". Cogent engineering, 4: 1376488, 2017.

[15] American Water Works Association. Water Quality and Treatment, $5^{\text {th }}$ ed., McGraw-Hill, Inc., New York, 1999.

[16] Langmuir, I. "The constitution and fundamental properties of solids and liquids". J. A. Chem. Soc. 38, pp. $2221-2295,1916$.

[17] Freundlich, H. M. F. "Uber die adsorption in losungen". Z. Phys. Chem. 57 pp. 385 - 470, 1906.

[18] Mesdaghinia, A., Rafiee, M. T., Vaezi, F. and Mahvi, A. H. "Evaluation of ferric chloride and alum efficiencies in enhanced coagulation for TOC removal and related residual metal". Iran. J. Environ. Health Sci.Eng.,2(3), pp. 189- 194, 2005

[19] Pollard, S.J.T., Fowler, G.D., Solars, C. J. and Perry, R. "Low-cost adsorbents for waste and wastewater treatment: a Review". Science of the Total Environment, 116 (1-2), pp. 31-52, 1992.

[20] Ali, E. N., Muyibi, S. A., Salleh, H. M., Alam, M. Z. and Salleh, M.R.M. "Production technique of natural coagulant from Moringa Oleifra seeds". Fourteenth International Water Technology Conference pp. 95 103,2010

[21] Aho, I. M. and Lagasi, J. E. "A new water treatment system using Moringa oleifera seed". American Journal of Scientific and Industrial Research, pp. 36, $487-492,2012$

[22] Ghebremichael, K. A. Moringa seed and pumice as alternative natural materials for drinking water treatment. KTH Land and Water Resources Engineering, 2004.

[23] Schwartz D. Water clarification using Moringa Oleifera. gate Technical Information W1e, Eschborn, Germanay, 2000.

[24] British Standard Institution, BS 410. Specification for test sieves. British Standard Institution, London, United Kingdom, 1986.

[25] American Public Health Association. Standard Methods for the Examination of Water and Wastewater(20th ed.). USA: Author, 1998.

[26] Bhatt, A. S., Sakaria, P. L., Vasudevan, M., Pawar, R.R., Sudheesh, N., Bajaj, H. C. and Mody, H.M. Adsorption of an anionic dye from aqueous medium by organoclays: equilibrium modeling, kinetic and thermodynamic exploration, RSC Advances, 2, pp. 8663-8671, 2012. 